\title{
THE ROLE OF INSTITUTIONAL DISTANCE, BUSINESS GROUP AFFILIATION AND OWNERSHIP LEVEL IN CROSS-BORDER M\&AS OF TURKISH FIRMS*
}

\author{
Asst. Prof. Ayşe KAYACI \\ Dicle University, FEAS, Diyarbakır,Turkey, (ayse.kayaci@dicle.edu.tr)
}

\begin{abstract}
Institutional environment has become a key phenomenon for internationalization studies of emerging market firms. As the presence of emerging market firms has increased in global economy, the investigation of the impacts of institutional environment on internationalization has become vital. The aim of this study is to examine the impacts of formal and informal institutional environment differences and business group affiliation on the choice of ownership level in cross border merger and acquisitions of Turkish firms. The study has analyzed 280 completed cross border merger and acquisitions of Turkish firms between years 1987-2018. As the formal institutional distance increases, Turkish firms prefer lower level of equity ownership. In contrast, Turkish firms prefer higher level of ownership as the informal institutional distance increases. Moreover, business group affiliation has a mitigating effect only in informal institutional distance and ownership level relationship.
\end{abstract}

Keywords: Cross Border Merger and Acquisitions, Emerging Markets, Institutional Distance, Turkey, Business Groups.

\section{TÜRK ŞIRKETLERININN ULUSLARARASI BİRLEŞME VE SATIN ALMALARINDA KURUMSAL ÇEVRENIN, IŞLETME GRUBUNA BAĞLI OLMANIN VE SAHIPLIIK DERECESININ ROLÜ}

\begin{abstract}
ÖZET
Kurumsal çevre kavramı, gelişmekte olan ülke şirketlerinin uluslararasılaşması yazınında bir fenomen hâline gelmiştir. Gelişmekte olan ülke şirketlerinin küresel ekonomideki görünürlükleri arttıkça bu şirketlerin uluslararasılaşmasını etkileyen kurumsal çevre değişkenlerini dikkate almak önemli hâle gelmiştir. Bu çalışmanın amacı, resmi ve gayrı resmi kurumsal çevre farklılıklarının ve işletme grubuna bağlı olmanın, Türk şirketlerinin uluslararası birleşme ve satın almalarında sahiplik derecesine etkilerini incelemektir. Çalışma 1987 ve 2018 yılları arasında Türk şirketleri tarafindan tamamlanmış 280 uluslararası birleşme ve satın almayı incelemiştir. Türk şirketleri resmi kurumsal mesafe arttıkça düşük seviyede sahiplik düzeyi tercih etmektedir. Öte yandan Türk şirketleri gayrı resmi kurumsal mesafe arttıkça yüksek seviyede sahiplik düzeyini tercih etmektedir. Ayrıca, işletme grubuna bağlı olmanın sadece gayrı resmi kurumsal mesafenin sahiplik derecesi ile ilişkisinde zayıflatıcı etkisi tespit edilebilmistir.
\end{abstract}

Anahtar Kelimeler: Uluslararası Birleşme ve Satın Almalar, Gelişmekte Olan Ekonomiler, Kurumsal Mesafe, Türkiye, İsletme Gruplart.

\footnotetext{
* This study is an extended and developed version of the proceeding which was presented with the title "Effects of Institutional Distance and Business Group Affiliation on Ownership Level in Cross-border M\&As: Turkey Contex" at 18th International Business Conference that is organized in Osmaniye at 02-04 May 2019.
}

www.ijmeb.org ISSN:2147-9208 E-ISSN:2147-9194

http://dx.doi.org/10.17130/ijmeb.798535

Received: 30.07.2019, Accepted: 28.06.2020 


\section{Introduction}

Expansion of neo liberal economy policies in world's different regions and development of information technologies have dramatically changed the direction of foreign direct investment (FDI) and geographic origin of multinational corporations (MNCs) in recent years (Child \& Rodrigues, 2005:384). In 2018, outward FDI (OFDI) from emerging markets (EMs) has reached $\$ 417$ billion that goes after the value of $\$ 558$ billion OFDI from developed markets in spite of the decrease in global FDI investments (UNCTAD, 2019:2). Accordingly, as an EM, Turkey has also increased its OFDI in the last decade via cross-border merger and acquisitions (M\&As). For example, Turkish cross-border M\&As has got \$1856 million net sales value in 2016 (UNCTAD, 2017:231).

Due to increased OFDI activity of EM firms, scholars have directed their attention to internationalization of EM firms which are started to called as emerging multinational corporations (EMNCs) (Ramamurti, 2009:3; Cuervo-Cazurra, 2012:156; Buckley, 2017:76). Despite the increased scholarly interest for EMNCs accelerated internationalization that generally depends on cross-border M\&As, the determinants of equity ownership level of EMNCs in cross-border M\&As have been still a growing research area and need to be investigated for further research (Mathews, 2006:13). Moreover, EMs have shown a significant level of heterogeneity among each other which would also effect strategic decisions of MNCs from these markets (Hoskisson et al., 2013:1296). As a result, institution-based view would be a solid base for understanding strategic choices like ownership level of EMNCs in cross-border investments.

The study adopts a multi-level perspective to incorporate both macro and micro institutional context constraints when investigating the antecedents of cross-border M\&As of EMNCs, especially Turkish MNCs. The study has aimed to contribute to present literature in two domains. First, it would be possible to understand how country-specific advantages (CSAs) and firm-specific advantages (FSAs) employ significant roles in EMNCs' outward internationalization (Rugman \& Verbeke, 2003:127). Furthermore, the study would expand the understanding about the heterogeneity of EM contexts by investigating the main antecedents of ownership level of cross-border M\&As of Turkish MNCs as a different EM. Research about EMs argues that differences in research findings of EMNCs internationalization compared to developed markets can be related to diverse conditions presented by these markets. For example, Turkey has an interesting contextual setting as a late-industrializing country which has integrated to world capital system via liberalization policies in the early 1980s. However, neo-liberal transformation of economy has not changed main economic actors in Turkey's economy which are state-created, family controlled and highly diversified big business groups (BGs). BGs have been emerged as a consequence of market imperfections and institutional voids. These voids in markets and institutions occur as information asymmetries, poor contract enforcement and imperfect regulatory structures in Turkey (Buğra, 1995:214; Yamak \& Üsdiken, 2006:191; Colpan, 2010:510; Yildirim-Öktem \& Üsdiken, 2010:126). Hence, national business systems and their effects on firm strategy should also be regarded while exploring EM firms' internationalization. Therefore, the current study could give insights about how differences in institutional context of home and host countries would affect the ownership level of acquired firms in cross-border M\&As of EM firms. Moreover, the role of BG affiliation as a FSA for EM firms would be explained in this ownership level and institutional distance relations. 
This paper has organized as follows: First theoretical background about the relations between the variables of the study and hypotheses developed has been provided. Second, the data gathering process and measurements of variables have been explained. Lastly, results, implications and limitations of the study have been presented.

\section{Theoretical Background and Hypotheses Development}

EMNCs have generally use cross-border M\&As like a springboard to access new markets and get strategic assets as a form of OFDI from EMs. This strategic asset seeking OFDI by EMNCs have been called as accelerated internationalization in the related lietrature (Mathews, 2006:13; Luo \& Tung, 2007:482). By Cross-border M\&As, EMNCs have the opportunity to compete with advanced MNCs in both local and international markets and to overcome the "liability of emergingness" problem (Madhok \& Keyhani, 2012:28; Lebedev et al., 2015:658). Moreover, EMNCs can get the benefit of economies of scale, foreign market exploitation and potential rare resources via cross-border M\&As (Chakrabarti et al., 2009:216).

As institution based view proposes that institutions define the "rules of the game" among interactions of organizations (North, 1990:3) and firm behavior as cognitive, rule-based and regulatory constructs (Scott, 1995:33). As a result, institutions have a significant role to reduce uncertainty and transaction costs which provide a stable environment for firms in an economy (Hoskisson et al., 2000:252-253). EMs generally suffer from unstable environments due to high level of institutional voids. Since EMNCs operate under institutional voids, they are in a less favorable position compare to advanced MNCs (Madhok \& Keyhani, 2012:30). Institutional voids in EMs may motivate EMNCs to escape from these markets and to enter institutionally distant environments (Cuervo-Cazurra, 2012:156). On the other hand, managing strategic decisions like cross-border investments can be more difficult in different formal and informal institutional contexts (Peng et al., 2009:67). For example, advanced MNCs prefer lower level of equity participation like joint ventures (JVs) over wholly owned subsidiaries (WOS) while entering EMs such as Turkey due to high political constraints and cultural distance which are the most significant constraints of institutional environment (Demirbag et al., 2007:428). As a consequence, EMNCs have to consider both formal and informal institutional environments in home and host countries while making cross-border investments.

\subsection{Equity Participation and Institutional Distance}

While expanding through cross-border M\&As, one of the most significant decision is the choice of equity participation level (Chari \& Chang, 2009:1278). The nature of the assets of a firm and uncertainty in its environment define the ownership choice in cross-border M\&As. As a consequence of this, the optimum level of equity participation or ownership level is a product of the costs and advantages of the transactions among these constraints and information asymmetry (Anderson \& Gatignon, 1986:6; Chari \& Chang, 2009:1291). However, the effects of institutional distance between home and host countries on the ownership level in crossborder M\&As of EMNCs have shown mixed results in the related literature so far (Chari \& Chang, 2009:1292; Yang, 2015:233; Liou et al., 2016:606, 2017; Malhotra et al., 2016:2000). These diverse and mixed results would necessitate to examine the relationship between institutional environment differences and the ownership choice in cross-border M\&As for 
different EM firms. EMNCs should also follow the "rules of the game" like developed market MNCs while investing in foreign markets and decide via considering the market potential, the natural resources, the economic freedom and business friendly environment of the host country (Pablo, 2009:867; Yang \& Deng, 2017:14). In addition to host country institutional environment, EMNCs have also been affected by their home countries' institutional contexts. For instance, Chinese MNCs have been motivated by "Go Global" policy of Chinese state and increased their cross-border M\&As in the previous decade (Peng, 2012:98). On the other hand, most of the EMs are known for high institutional voids in their business environments which may motivate EMNCs to expand in foreign markets and cause escapist OFDI (Stoian \& Mohr, 2016:1132). As a result, EMNCs may prefer a risky approach and choose higher level of ownership in cross-border M\&As to manage intangible assets of target firm effectively and expand their operational base (Deng, 2009:77). Whether motivated by push or pull factors of home country and host country, EMNCs have been affected by institutional environment constraints while internationalizing and these constraints should be evaluated to understand cross-border investment decisions.

Previous studies about entry mode choice have seen differences between institutional environments as the causes of high transaction costs since they cause uncertainty. Thus, it is expected that MNCs would choose lower level of ownership during foreign expansion (Williamson, 1979: 254; Anderson \& Gatignon, 1986:15). Furthermore, institutional and cultural context constraints have been seen as main antecedents of entry mode decisions since they have impact on the flexibility of firms and their legitimacy in host markets (Anderson \& Gatignon, 1986:15; Kostova \& Zaheer, 1999:70; Brouthers, 2002:215). Consequently, higher level of equity participation choices have been considered as more risky when entering in distant institutional environments (Brouthers \& Brouthers, 2000:95; Chari \& Chang, 2009:1293). On the contrary, the relevant literature has proposed inconsistent findings about the relationship between institutional distance and ownership level in cross-border M\&As of EMNCs. For example, Zhang et al. (2011:236) have proposed that quality of host country institutional environment would increase the likelihood of completion of Chinese crossborder M\&As in the relevant country. This result shows that perceived risk and uncertainty due to the institutional distance between home and host countries can work reversely for EMNCs. Correspondingly, Yang, (2015:233) and Pinto et al. (2017:542) have emphasized the diversified results of ownership choice of EMNCs compared to advanced market MNCs and proposed that as institutional distance increases between home and host countries, the equity participation level of EMNCs in cross-border M\&As would increase. Additionally, some of the studies have investigated the role of institutional distance with its sub-dimensions (formal and informal institutional distance) on the choice of ownership level. While formal institutional distance causes a higher level of ownership level in cross-border M\&As of EMNCs, informal institutional distance causes a lower level of ownership level (Contractor et al., 2014:938; Liou et al., 2017:290). Informal institutional distance has been generally measured through cultural distance in most of the related literature (Chakrabarti et al., 2009:230; Liou et al., 2016:609; Popli et al., 2016:405). Furthermore, formal institutional distance has been a key factor for MNCs to gain legitimacy and would have significant impact on ownership choices of these firms in foreign markets (Kostova \& Zaheer, 1999:70). However, some findings support that under higher formal institutional distance, EMNCs would prefer higher level of ownership 
since they have limited option to internationalize their operations (Gaffney et al., 2016:273). These contradictory results show that formal and informal distance constraints should be evaluated separately for different EM contexts. While some studies have provided support for mitigating effect of cultural distance or informal institutional distance on ownership level (Yang, 2015:233; Liou et al., 2016:290), others have claimed that cultural distance increases long run performance of cross-border acquisitions (Chakrabarti et al., 2009:230).

Earlier research about Turkish MNCs could not find significant relations between institutional distance and equity participation level in foreign subsidiaries (Demirbag et al., 2010:230; Ilhan-Nas et al., 2018:179). However, Turkish MNCs' have the ability to coopt with imperfect market conditions via relation-sourced capabilities and government support (Yaprak et al., 2018:205). As a consequence, investing in markets with high formal institutional distance would lead them to choose lower level of equity ownership to escape from risks and legitimacy problems in host markets. On the other hand, informal institutions may cause more uncertainty in post-acquisition period to integrate new management with settled managers and employees. As a result of this, Turkish MNCs would prefer higher level of ownership in culturally distant environments to reduce uncertainty in management issues and get benefit of high value added activities effectively. When considering both push and pull factors in institutional environment as motivators for cross border M\&As, it is highly possible that increased formal institutional distance between home and host countries will lead Turkish firms to choose lower equity ownership and increased informal institutional distance will cause higher equity ownership in cross border investments.

H1a: As formal institutional distance between home and host countries increase, Turkish MNCs would choose lower level of equity participation in target firms in cross border M\&As.

H1b: As informal institutional distance between home and host countries increase, Turkish MNCs would choose higher level of equity participation in target firms in cross border M\&As.

\subsection{The Role of Business Group Affiliation}

EM firms generally have concentrated ownership like BG affiliation, family ownership or state ownership (Lebedev et al., 2015:658). For instance, affiliate firms of BGs are controlled through cross-shareholdings which cause pyramidal BGs in EMs (Granovetter, 2005:433). Even if it seems that affiliate firms are controlled by diverse shareholders (individuals, other firms, public shareholders), the owner family can still control most of the firm's decisionmaking processes with indirect control via shares of other affiliates in that independent affiliate. As a conclusion, this indirect control would cause high level of ownership concentration in BGs affiliates. Previous studies about concentrated ownership and cross-border M\&As have found unfavorable results since concentrated ownership in acquiring firms cause negative impressions for investors (Chen \& Young, 2010:534; Bhaumik \& Selarka, 2012:725). Since owner families have risk averse perception in long term strategic decisions like internationalization, ownership concentration and family control diminishes equity participation level of EMNCs in their foreign affiliates (Filatotchev et al., 2007:566). Even if concentrated ownership or family control have been beneficial in imperfect markets, they have been seen as detrimental in cross- 
border M\&As of EM firms (Khanna \& Palepu, 2000:278; Bhaumik et al., 2010:448). Also, protection of minority shareholders is lower in EMs and majority shareholders can easily dominate long term strategic decisions of EM firms (Filatotchev \& Wright, 2010:476-477). In accord with this, family ownership in EM firms may restrain internationalization level of these firms (Singla et al., 2017:141). On the other hand, the concern for survival and wealth transfer to younger generations can increase firm performance and change the attitudes of owner families about long run strategies (Anderson \& Reeb, 2003:1324). Previous literature about EM firms provides evidence about the positive effect of family involvement and ownership in BG affiliates on international expansion and growth of these affiliates (Chung, 2014:269; Singh \& Delios, 2017:624). Furthermore, being affiliated to a BG has also supports to being first movers and entrants in M\&A waves since affiliates can easily use BGs resources and capabilities (Fuad $\&$ Sinha, 2018:936). These findings have supported that institutional context in EMs can also have impact on cross-border investments through creating significant organizational structures like BGs.

\section{Figure 1: The Proposed Research Model}

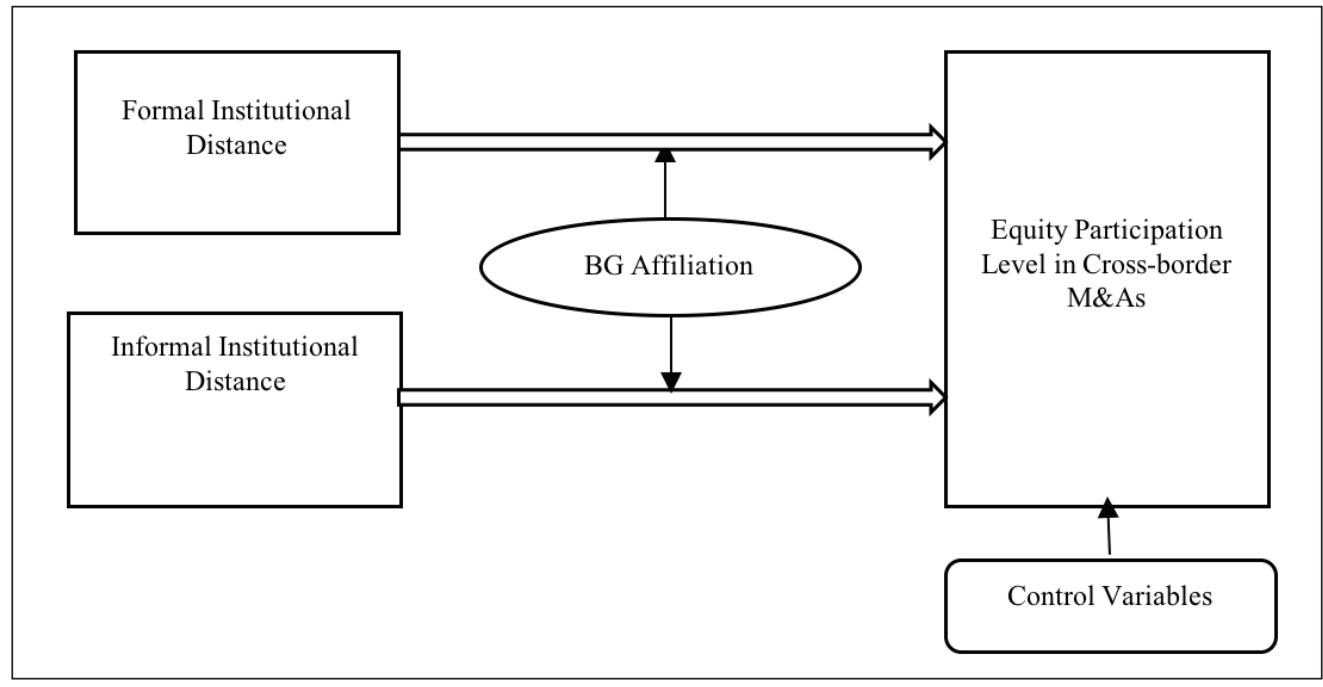

As mentioned before, EMNCs have shown diversified choices in their cross-border M\&As related to formal and informal institutional distances. Beside the harmful effects of concentrated ownership on long term strategic decisions of EMNCs, maximizing wealth and reputation of majority shareholders could be important when analyzing the relationship between institutional distance and equity participation level in cross-border M\&As (Filatotchev et al., 2007:466; Bhaumik et al., 2010:448). Although earlier research has focused on the contextual role of institutional distance on the relationship between concentrated ownership of acquiring firm and equity participation level (Filatotchev et al., 2007:569; Ilhan-Nas et al., 2018:180), it should be regarded that risk taking approach of majority shareholders in acquiring firms can increase the power of the relationship between institutional distance and ownership choice in cross-border 
M\&As. Since firms in Turkey generally have high level of concentrated ownership and this manifests itself as pyramidal family BGs (Yurtoglu, 2000:216), it is important to consider BG affiliation as a contextual variable which shapes internationalization decisions of Turkish firms. Owner families in Turkish BGs generally prefer pyramidal ownership to gain full control on affiliate firms and tunnel profits among them (Colpan, 2010:511). Even if previous findings could not find out direct effect of concentrated ownership on equity participation level of Turkish firms in foreign subsidiaries (Demirbag et al., 2010:288; Ilhan-Nas et al., 2018:180), this characteristic can work as a driver for established relations. Therefore, the mitigating effect of formal institutional distance on the ownership level of cross-border M\&As of Turkish MNCs would be higher when these firms are affiliated to BGs. Since gaining legitimacy would be more difficult for BG affiliated firms in distant institutional environments, higher formal institutional distance effect would increase for BGs' affiliates cross-border investments. On the other hand, owner families of affiliate firms can control their foreign acquisitions in culturally distant environments through full control to integrate target firms and manage their valuable resources. As a result, the proposed research model can be seen in Figure 1.

H2a: BG affiliation of Turkish firms would increase the effect of formal institutional distance on equity participation level in target firms for cross-border M\&As

H2b: BG affiliation of Turkish firms would increase the effect of informal institutional distance on equity participation level in target firms for cross-border M\&As.

\section{Methodology}

\subsection{Sample Selection}

The sample of the study consists of 280 cross-border M\&As by Turkish firms that are completed between 1987 and 2018. Thomson Reuters EIKON database has been used to acquire cross-border deal information and sample formation. Thomson Reuters database is the most widely used database for cross-border investment studies in the literature (Yang, 2015:228; Liou et al., 2017:285). The sample has involved all completed cross-border M\&A deals which are available in the database and made by Turkish firms.

None of the completed deals have been eliminated from the sample not to reduce sample size and to project most of the internationalization efforts of Turkish firms for a long time period. The details of the sample can be seen in Table 1. It seems that Turkish firms prefer to acquire firms in European region which is geographically and historically close to Turkey. Half of the firms have made acquisitions in related industries. Moreover, the sample distributed almost equally between BG affiliated and non-affiliated firms. In general, Turkish firms seek to acquire target firms in both advanced and developing markets for cross-border investments. Consequently, the study sample seems to be moderately distributed across industries, target regions, ownership status and target development status. 
Table 1: Major Features of Cross-border M\&A Deals of Turkish Firms

\begin{tabular}{lcclrr}
\hline $\begin{array}{l}\text { Acquirer BG } \\
\text { Affiliate Status }\end{array}$ & $\mathbf{n}$ & $\boldsymbol{\%}$ & $\begin{array}{l}\text { Target Country } \\
\text { Status (IMF) }\end{array}$ & $\mathbf{n}$ & $\boldsymbol{\%}$ \\
\hline Affiliate & 157 & 56.07 & Advanced & 155 & 55.36 \\
\hline Non-affiliate & 123 & 49.93 & Developing & 125 & 44.64 \\
\hline Total & 280 & 100 & Total & 280 & 100 \\
\hline $\begin{array}{l}\text { Target } \\
\text { Region }\end{array}$ & $\mathbf{n}$ & $\boldsymbol{\%}$ & $\begin{array}{l}\text { Industry } \\
\text { Relatedness }\end{array}$ & $\mathbf{n}$ & $\boldsymbol{\%}$ \\
\hline Africa/Middle East/Central Asia & 37 & 13.21 & Related & 141 & 50.36 \\
\hline Americas & 29 & 10.36 & Not-related & 139 & 49.64 \\
\hline Asia Pacific Excluding Central Asia & 13 & 4.34 & & & \\
\hline Europe & 200 & 71.43 & & & \\
\hline Japan & 1 & 0.36 & & 280 & 100 \\
\hline Total & 280 & 100 & Total & & \\
\hline
\end{tabular}

\subsection{Variables and Measurement}

The sources of data and measurement of all operationalized variables are listed in Table 2. The dependent variable of the study is equity participation level of Turkish firms in crossborder M\&As and is measured as the percentage which is acquired during cross-border deal. The measure is ranged from $0,1 \%$ to $100 \%$ and is a continuous variable. The dependent variable is available in EIKON database for every completed deal. Measuring equity participation level as a continuous variable can give more accurate results than measuring it with a binary variable since it can give the real effects of change between 50\% and 75\% (Yang, 2015:229).

The first independent variable is formal institutional distance and is measured by Index of Economic Freedom which is developed by Heritage Foundation. This index provides the degree of formal institutional development of economies according to 12 freedom factors that are grouped into four general categories which are rule of law (i.e. property rights, government integrity, judicial effectiveness), government size (i.e., government spending, tax burden, fiscal health), regulatory efficiency (i.e., business freedom, labor freedom, monetary freedom) and open markets (trade freedom, investment freedom, financial freedom) (The Heritage Foundation, 2018). Formal institutional distance is calculated through the difference between overall economic freedom index of target country and Turkey for the year of completed deal. The second independent variable is informal institutional distance which is measured through cultural distance between target countries and Turkey that depends on Hofstede (2001)'s four cultural dimensions (power distance, uncertainty avoidance, individualism and masculinity). Cultural distance between home and host countries is calculated through Kogut \& Singh's (1988) index:

$$
C D_{j}=\sum_{i=1}^{4}\left\{\left(I_{i j}-I_{i u}\right)^{2} / V_{i}\right\} / 4
$$


where $I_{i j}$ means the Turkey's country score for Hofstede's national culture dimension i, $I_{i u}$ is the target country score for cultural dimension $i$ and $V_{i}$ is the variance value of cultural dimension $i$.

The moderator variable is BG affiliation and measured by a dummy variable which is coded as 1 if the acquiring firm is affiliated to a BG and 0 otherwise. This data collected through web sites and annual reports of acquiring firms. The control variables of the study is industry relatedness, deal size and target market size. Industry relatedness is measured by a dummy variable and the data is available in EIKON database which defines target and acquiring firms' industries. Deal size is also collected through EIKON database which is measured though million US dollars. Target market size is measured through target country GDP Per Capita and that data is gathered through The World Bank database.

Table 2: Variable Name, Measures and Data Sources

\begin{tabular}{lll}
\hline Variable Name & Measurement & Data Source \\
\hline $\begin{array}{l}\text { Equity Participation } \\
\text { Level }\end{array}$ & $\begin{array}{l}\text { The percentage of equity acquired } \\
\text { after the acquisition deal ranges } \\
\text { between } 0.1 \% \text { and } 100 \%\end{array}$ & Thomson Reuters EIKON \\
\hline $\begin{array}{l}\text { Formal Institutional } \\
\text { Distance }\end{array}$ & $\begin{array}{l}\text { The overall index of economic } \\
\text { freedom based on 12 factors }\end{array}$ & Heritage Foundation \\
\hline $\begin{array}{l}\text { Informal Institutional } \\
\text { Distance }\end{array}$ & $\begin{array}{l}\text { Kogut and Singh's (1988) cultural } \\
\text { distance formula }\end{array}$ & $\begin{array}{l}\text { (www.hofstede-insights.com; } \\
\text { Bofstede, 2001) }\end{array}$ \\
\hline BG Affiliation & $\begin{array}{l}\text { A dummy coded variable whether } \\
\text { the acquiring firm is affiliated a }\end{array}$ & $\begin{array}{l}\text { Annual reports and company } \\
\text { web sites }\end{array}$ \\
\hline Industry Relatedness & $\begin{array}{l}\text { If target and acquiring firm are in } \\
\text { the same industry=1/0 }\end{array}$ & Thomson Reuters EIKON \\
\hline Deal Size & $\begin{array}{l}\text { The US dollar value of each } \\
\text { completed deal }\end{array}$ & Thomson Reuters EIKON \\
\hline Target Market Size & \begin{tabular}{l} 
GDP Per Capita of target country \\
\hline
\end{tabular} & The World Bank \\
\hline
\end{tabular}

\section{Results}

Descriptive statistics and correlation matrix of all variables is presented in Table 3 . The variance in the number of observations is a result of missing values for some variables which are gathered from The World Bank and Heritage Foundation. As seen in Table 3, correlations among variables are not so high for concerning multicollinearity issues. However, all the variables is tested and all of the variance inflation factor (VIF) values are below 10 which shows that no violation for multicollinearity (Belsley et al., 1980). The highest correlation is between formal institutional distance and target market size (0.700). This result show how formal institutional development and market development in an economy goes hand in hand in general terms. Similarly, cultural distance and target market size has a highly correlated relation (0.662). It also seems that both formal and informal institutional distances are related to each other and can have replaceable relations with the dependent variable. 
Table 3: Descriptive Statistics and Correlations

\begin{tabular}{|c|c|c|c|c|c|c|c|c|c|c|}
\hline Variables & n & Mean & SD & (1) & (2) & (3) & (4) & (5) & (6) & $(7)$ \\
\hline $\begin{array}{l}\text { Equity Participation } \\
\text { Level (1) }\end{array}$ & 280 & 66.49 & 37.22 & 1 & & & & & & \\
\hline $\begin{array}{l}\text { Formal Institutional } \\
\text { Distance (2) }\end{array}$ & 269 & 3.77 & 10.82 & -0.000 & 1 & & & & & \\
\hline $\begin{array}{l}\text { Informal } \\
\text { Institutional } \\
\text { Distance (3) }\end{array}$ & 244 & 1.49 & 1.13 & $0.170^{*}$ & $0.642^{* * *}$ & 1 & & & & \\
\hline BG Affiliation (4) & 280 & 1.43 & 0.49 & $0.151^{*}$ & -0.027 & 0.053 & 1 & & & \\
\hline $\begin{array}{l}\text { Industry } \\
\text { Relatedness (5) }\end{array}$ & 280 & 1.50 & 0.50 & -0.005 & -0.032 & 0.047 & 0.068 & 1 & & \\
\hline Deal Size (6) & 280 & 45.10 & 163.60 & 0.109 & -0.053 & 0.001 & -0.111 & 0.002 & 1 & \\
\hline $\begin{array}{l}\text { Target Market } \\
\text { Size (7) }\end{array}$ & 272 & 24.97 & 20.15 & 0.113 & $0.700^{* * *}$ & $0.662^{* * *}$ & 0.073 & -0.090 & -0.003 & 1 \\
\hline
\end{tabular}

The proposed hypotheses are tested through multiple linear regression analysis. Table 4 presents four different models and analytical results of the study. The impact of all control variables on the dependent variable are tested by Model 1. Model 2 is tested the effect of independent variables and control variables on the dependent variable. Model 3 and Model 4 are tested the impact of moderator variable on the relationships between the independent and dependent variables. There is variance across observations in different models because of missing values in some variables as mentioned before.

Table 4: Regression Results for Equity Participation Level in Cross-border M\&As of Turkish Firms

\begin{tabular}{|c|c|c|c|c|}
\hline Variables & Model 1 & Model 2 & Model 3 & Model 4 \\
\hline \multirow{2}{*}{ Formal Institutional Distance } & & $-0.772^{* *}$ & -0.572 & $-0.722^{* *}$ \\
\hline & & $(0.32)$ & $(0.36)$ & $(0.32)$ \\
\hline \multirow{2}{*}{ Informal Institutional Distance } & & $7.982^{* * * *}$ & $7.598^{* *}$ & $10.69^{* * *}$ \\
\hline & & $(3.01)$ & $(3.00)$ & $(3.37)$ \\
\hline \multirow{2}{*}{ BG Affiliation } & & & $11.87^{* *}$ & $22.79^{* * * *}$ \\
\hline & & & $(5.34)$ & $(8.20)$ \\
\hline \multirow{2}{*}{ BG Affiliation X Formal Institutional Distance } & & & -0.278 & \\
\hline & & & $(0.44)$ & \\
\hline \multirow{2}{*}{ BG Affiliation X Informal Institutional Distance } & & & & $-8.061^{*}$ \\
\hline & & & & $(4.34)$ \\
\hline
\end{tabular}


Table 4 continued

\begin{tabular}{lcccc}
\hline \multirow{2}{*}{ Industry Relatedness } & -0.652 & -1.100 & -1.777 & -2.768 \\
\cline { 2 - 5 } Deal Size & $(4.49)$ & $(4.89)$ & $(4.88)$ & $(4.87)$ \\
\hline \multirow{2}{*}{ Target Market Size } & 0.010 & 0.023 & $0.026^{*}$ & $0.026^{*}$ \\
\cline { 2 - 5 } & $(0.01)$ & $(0.01)$ & $(0.01)$ & $(0.01)$ \\
\hline \multirow{2}{*}{ Constant } & $0.000^{* * *}$ & 0.000 & 0.000 & 0.000 \\
\hline F & $(0.00)$ & $(0.00)$ & $(0.00)$ & $(0.00)$ \\
\hline Observations & $57.58^{* * *}$ & $53.82^{* * *}$ & $50.45^{* * *}$ & $46.62^{* * *}$ \\
\hline R-squared & $(4.46)$ & $(5.48)$ & $(5.67)$ & $(6.04)$ \\
\hline
\end{tabular}

Standard errors in parentheses $(* * * \mathrm{p}<0,01 ; * * \mathrm{p}<0,05 ; * \mathrm{p}<0,1)$

H1a has proposed that as formal institutional distance between target countries and Turkey increase, Turkish firms will seek for lower level of equity participation in cross-border M\&A deals. As shown in Model 2, formal institutional distance is significantly and negatively related to equity participation level $(\beta=-0.772, \mathrm{p}<0.05)$ which gives support to H1a and shows that Turkish firms prefer lower level of ownership while entering a target country with a larger formal institutional distance. Furthermore, $\mathrm{H} 1 \mathrm{~b}$ has stated that an increase in informal institutional distance would lead Turkish firms to prefer higher level of equity participation in cross-border M\&A deals. This hypothesis is also supported by Model 2 in which informal institutional distance coefficient is positive and significant $(\beta=7.982, p<0.001)$. Therefore, Turkish firms seem to have higher level of ownership position when entering in culturally distant environments.

In terms of moderating effect of BG affiliation, the interaction between BG affiliation and formal institutional distance does not have a significant coefficient $(\beta=-0.278, p>0.1)$ which can be seen in Model 3. As a result, H2a which states that firms would prefer lower level of equity participation when formal institutional distance is high and this relationship would be stronger for firms affiliated to BGs is rejected. Meanwhile, the interaction coefficient for BG affiliation and informal institutional distance has a significant but negative value $(\beta=-8.061$, $\mathrm{p}<0.1$ ) which contradicts the proposition of $\mathrm{H} 2 \mathrm{~b}$. Thus, $\mathrm{H} 2 \mathrm{~b}$ is also rejected. It seems that BG affiliates prefer lower level of equity participation respect to non-affiliated firms when entering in culturally distant markets.

As for the effect of control variables, target market size and deal size have shown significant relationships with the dependent variable. These results are in consistent with previous findings (Liou et al., 2016:609; Pinto et al., 2017:540). Turkish firms tend to acquire greater shares in cross-border M\&As when deal size and target market size is bigger. 


\section{Discussion and Concluding Remarks}

As global presence and investments of EMNCs increase, it would be still significant to consider different types of EM firms and their cross-border investments respect to different institutional contexts and firm characteristics. Strategies and structural choices of MNCs have been shaped by both home and host countries and they tend to have lower level of ownership in target countries to overcome legitimacy and uncertainty problems (North, 1990:3; Kostova \& Zaheer, 1999:70). However, the accelerated catch-up strategies of EMNCs have shown a different pattern when entering in foreign markets via cross-border M\&As. Despite advanced MNCs' concern for uncertainty in host countries, EMNCs' ownership choice has been shaped by legitimacy concerns and escaping motives (Cuervo-Cazurra, 2012:156; Madhok \& Keyhani, 2012:30). In so doing, this study contributes to EMNCs literature by examining cross-border M\&A activity of Turkish firms via institution-based view.

The findings of the study demonstrate that Turkish firms undertaking cross-border M\&As prefer lower level of equity participation when formal institutional distance is high. This finding contradicts with previous studies about other EM firms and their cross-border investments (Contractor et al., 2014:938; Yang, 2015:233; Liou et al., 2017:290; Pinto et al., 2017:542). However, ownership choice of Turkish firms is consistent with the general view about transaction costs and uncertainty avoidance view (Anderson \& Gatignon, 1986:15). This shows that not all EM firms seek for legitimacy in institutionally developed markets during cross-border acquisitions. Since Turkish firms have been known for their market-seeking attitude and entering in economically similar markets for internationalization the beginning (Yaprak et al., 2018:205), it seems reasonable that some EMNCs may be risk averse like advanced market MNCs while investing in markets with different formal institutional contexts. In the case of Turkish MNCs, regulated institutional environments can cause more uncertainty to firms which are used to perform under institutional voids. In contrast to formal institutional distance, Turkish MNCs tend to increase their equity participation level when they acquire a target firm in a country with high informal institutional distance. Related to Malhotra et al.'s (2011:328) findings about cultural distance, this finding has been separated from previous studies. The choice of getting higher ownership participation in culturally distant markets may show that Turkish firms concern about uncertainty and conflicts in cross-border investments more in after acquisition period than pre-acquisition period. While macro institutional context variables have shown significant effects of equity participation level of Turkish MNCs, a micro institutional context variable has shown no significant contribution. The study has posited that BG affiliation as a micro institutional context variable (Yiu, 2011:250) would intensify the institutional distance effects of equity participation level. Despite expected relations and directions, affiliations of BGs have not shown differing choices in equity participation respect to non-affiliated firms in target markets with higher formal institutional distance. Similarly, the interaction effect of BG affiliation has exposed a mitigating effect on the positive relation between informal institutional distance and equity participation level. Although concentrated ownership has been evaluated as the reason for risk taking approach in strategic decisions, affiliate firms has implied a risk averse approach for culturally distant markets. This shows that majority shareholders can be more sensitive about managing inner relations of acquired firms than outside relations with formal institutions. 
Like other research, the study has some limitations due to contextual or time related constraints. First of all, the study has only examined Turkish firms with a relatively small sample size. Also, this study has only considered cross-border M\&As for internationalization activity of EMNCs. Greenfield investments can be examined for future research to understand the effects of formal and informal institutions on FDI projects of EM firms. Additionally, concentrated ownership variable has been measured as a dummy variable which can hardly give sensitive statistical results in cross-sectional analysis due to limited sample size of the study. In future studies, the ratio of majority shareholders should be employed to get more robust results. Besides, minority shareholder protection constraint can be added to research models while determining ownership level of EMNCs in cross-border investments. Consequently, the study has given vital contributions about how institution based view can work differently in specific EM contexts and provided an understanding about hybrid behaviors of EMNCs.

\section{References}

Anderson, E., \& Gatignon, H. (1986). Modes of foreign entry: A transaction cost analysis and propositions. Journal of International Business Studies, 17(17), 1-26.

Anderson, R. C., \& Reeb, D. M. (2003). Founding-family ownership and firm performance: Evidence from the S\&P 500. The Journal of Finance, 58(3), 1301-1328.

Belsley, D. A., Kuh, E., \& Welsch, R. E. (1980). Regression diagnostics: Identifying influental data and sources of collinearity. Hoboken, NJ, USA: John Wiley \& Sons, Inc.

Bhaumik, S. K., Driffield, N., \& Pal, S. (2010). Does ownership structure of emerging-market firms affect their outward FDI the case of the Indian automotive and pharmaceutical sectors. Journal of International Business Studies, 41(3), 437-450.

Bhaumik, S. K., \& Selarka, E. (2012). Does ownership concentration improve M\&A outcomes in emerging markets?: Evidence from India. Journal of Corporate Finance, 18(4), 717-726.

Brouthers, K. D. (2002). Institutional, cultural and transaction cost influences on entry mode choice and performance. Journal of International Business Studies, 33(2), 203-221.

Brouthers, K. D., \& Brouthers, L. E. (2000). Acquisition or greenfield start-up? Institutional, cultural and transaction cost influences. Strategic Management Journal, 21(1), 89-97.

Buckley, P. J. (2017). Internalisation theory and outward direct investment by emerging market multinationals. Management International Review, 1-30.

Buğra, A. (1995). Devlet ve işadamlarl: State and business in modern Turkey; A comparative study. İletişim Yayınları.

Chakrabarti, R., Gupta-Mukherjee, S., \& Jayaraman, N. (2009). Mars-Venus marriages: Culture and cross-border M \& A. Journal of International Business Studies, 40(2), 216-236.

Chari, M. D., \& Chang, K. (2009). Determinants of the share of equity sought in cross-border acquisitions. Journal of International Business Studies, 40(8), 1277-1297.

Chen, Y. Y., \& Young, M. N. (2010). Cross-border mergers and acquisitions by Chinese listed companies: A principal-principal perspective. Asia Pacific Journal of Management, 27(3), 523-539.

Child, J., \& Rodrigues, S. B. (2005). The internationalization of Chinese firms: A case for theoretical extension? Management and Organization Review, 1(3), 381-410.

Chung, H. M. (2014). The role of family management and ownership on semi-globalization pattern of globalization: The case of family business groups. International Business Review, 23(1), 260-271. 
Colpan, A. M. (2010). Business groups in Turkey. In A. M. Colpan, T, Hikino, J. R. Lincoln (Eds.), The Oxford handbook of business groups (pp. 486-525). Oxford University Press.

Contractor, F. J., Lahiri, S., Elango, B., \& Kundu, S. K. (2014). Institutional, cultural and industry related determinants of ownership choices in emerging market FDI acquisitions. International Business Review, 23(5), 931-941.

Cuervo-Cazurra, A. (2012). Extending theory by analyzing developing country multinational companies: Solving the Goldilocks debate. Global Strategy Journal, 2(3), 153-167.

Demirbag, M., Glaister, K. W., \& Tatoglu, E. (2007). Institutional and transaction cost influences on MNEs' ownership strategies of their affiliates: Evidence from an emerging market. Journal of World Business, 42(4), 418-434.

Demirbag, M., McGuinness, M., \& Altay, H. (2010). Perceptions of institutional environment and entry mode. Management International Review, 50(2), 207-240.

Demirbag, M., Tatoglu, E., \& Glaister, K. W. (2010). Institutional and transaction cost determinants of Turkish MNEs' location choice. International Marketing Review, 27(3), 272-294.

Deng, P. (2009). Why do Chinese firms tend to acquire strategic assets in international expansion? Journal of World Business, 44(1), 74-84.

Filatotchev, I., Stephan, J., \& Jindra, B. (2007). FDI by firms from newly industrialised economies in emerging markets: Corporate governance, entry mode and location. Journal of International Business Studies, 38(4), 556-572.

Filatotchev, I., \& Wright, M. (2010). Agency perspectives on corporate governance of multinational enterprises. Journal of Management Studies, 48(2), 471-486.

Fuad, M., \& Sinha, A. K. (2018). Entry-timing, business groups and early-mover advantage within industry merger waves in emerging markets: A study of Indian firms. Asia Pacific Journal of Management, 35(4), 919-942.

Gaffney, N., Karst, R., \& Clampit, J. (2016). Emerging market MNE cross-border acquisition equity participation: The role of economic and knowledge distance. International Business Review, 25(1), 267-275.

Granovetter, M. (2005). Business groups and social organization. In N. J. Smelser, R, Swedberg (Eds.), The handbook of economic sociology (pp.429-450). New Jersey,USA: Princeton University Press.

Hofstede,G.(2001).Culture's consequences: Comparing values, behaviors, institutions and organizations across nations. Sage publications.

Hofstede Insights (no date). Retrieved from https://www.hofstede-insights.com/product/comparecountries/

Hoskisson, R. E., Eden, L., Lau, C. M. \& Wright, M. (2000). Strategy in emerging economies. The Academy of Management Journal, 43(3), 249-267.

Hoskisson, R. E., Wright, M., Filatotchev, I., \& Peng, M. W. (2013). Emerging multinationals from mid-range economies: The influence of institutions and factor markets. Journal of Management Studies, 50(7), 1295-1321.

Ilhan-Nas, T., Okan, T., Tatoglu, E., Demirbag, M., \& Glaister, K. W. (2018). The effects of ownership concentration and institutional distance on the foreign entry ownership strategy of Turkish MNEs. Journal of Business Research, 93, 173-183.

Khanna, T., \& Palepu, K. (2000). The future of business groups in emerging markets: Long-run evidence from Chile. The Academy of Management Journal, 43(3), 268-285. Retrieved from: http:// www.jstor.org/stable/1556395\%5Cnhttp://www.jstor.org/stable/1556395?seq=1\&cid=pdfreference\#references_tab_contents\%5Cnhttp://about.jstor.org/terms. 
Kogut, B., \& Singh, H. (1988). The effect of national culture on the choice of entry mode. Journal of International Business Studies, 19(3), 411-432.

Kostova, T., \& Zaheer, S. (1999). Organizational legitimacy under conditions of complexity: The case of the multinational enterprise. The Academy of Management Review, 24(1), 64-81.

Lebedev, S., Peng, M. W., Xie, E., \& Stevens, C. E. (2015). Mergers and acquisitions in and out of emerging economies. Journal of World Business, 50(4), 651-662.

Liou, R.-S., Chao, M. C., \& Ellstrand, A. (2017). Unpacking institutional distance: Addressing human capital development and emerging-market firms' ownership strategy in an advanced economy. Thunderbird International Business Review, 59(3), 281-295.

Liou, R. S., Chao, M. C.H., \& Yang, M. (2016). Emerging economies and institutional quality: Assessing the differential effects of institutional distances on ownership strategy. Journal of World Business, 51(4), 600-611.

Luo, Y., \& Tung, R. L. (2007). International expansion of emerging market enterprises: A springboard perspective. Journal of International Business Studies, 38(4), 481-498.

Madhok, A., \& Keyhani, M. (2012). Acquisitions as entrepreneurship: Asymmetries, opportunities, and the internationalization of multinationals from emerging economies. Global Strategy Journal, 2(1), 26-40.

Malhotra, S., Lin, X., \& Farrell, C. (2016). Cross-national uncertainty and level of control in cross-border acquisitions: A comparison of Latin American and U.S. multinationals. Journal of Business Research, 69(6), 1993-2004.

Malhotra, S., Sivakumar, K., \& Zhu, P. C. (2011). Curvilinear relationship between cultural distance and equity participation: An empirical analysis of cross-border acquisitions. Journal of International Management, 17(4), 316-332.

Mathews, J. A. (2006). Dragon multinationals: New players in 21st century globalization. Asia Pacific Journal of Management, 23(1), 5-27.

North, D. (1990). Institutions, institutional change, and economic performance. Economic Perspective, 5(1), 97-112.

Pablo, E. (2009). Determinants of cross-border M\&As in Latin America. Journal of Business Research, 62(9), 861-867.

Peng, M. W., Sun, S. L., Pinkham, B., \& Chen, H. (2009). The institution-based view as a third leg for a strategy tripod. Academy of Management Perspectives, 23(3), 63-81.

Peng, M. W. (2012). The global strategy of emerging multinationals from China. Global Strategy Journal, 107, 97-107.

Pinto, C. F., Ferreira, M. P., Falaster, C., Fleury, M. T. L., \& Fleury, A. (2017). Ownership in cross-border acquisitions and the role of government support. Journal of World Business, 52(4), 533-545.

Popli, M., Akbar, M., Kumar, V., \& Gaur, A. (2016). Reconceptualizing cultural distance: The role of cultural experience reserve in cross-border acquisitions. Journal of World Business, 51(3), 404412.

Ramamurti, R. (2009). Why study emerging-market multinationals? In R. Ramamurti, J. V. Singh (Eds.), Emerging multinationals in emerging markets (pp. 3-22). New York: Cambridge University Press.

Rugman,A.M.,\& Verbeke,A. (2003). Extending the theory of the multinational enterprise: Internalization and strategic management perspectives. Journal of International Business Studies, 34(2), 125137.

Scott, W. R. (1995). Institutions and organizations. Sage Publications. Retrieved from http://books. google.com/books?id=7Y-ObDCw_aEC 
Singh, D., \& Delios, A. (2017). Corporate governance, board networks and growth in domestic and international markets: Evidence from India. Journal of World Business, 52(5), 615-627.

Singla, C., George, R., \& Veliyath, R. (2017). Ownership structure and internationalization of Indian firms. Journal of Business Research, 81 (December 2016), 130-143.

Stoian, C., \& Mohr, A. (2016). Outward foreign direct investment from emerging economies: Escaping home country regulative voids. International Business Review, 25(5), 1124-1135.

The Heritage Foundation. (2018). Index of Economic Freedom. Retrieved August 14, 2018, from https:// www.heritage.org/index/about

UNCTAD. (2017). World Investment Report 2017: Investment and Digital Economy.

UNCTAD. (2019). World Investment Report 2019: Key Messages and Overview.

Williamson, O. E. (1979). Transaction-cost economics : The governance of contractual relations. The Journal of Law \& Economics, 22(2), 233-261.

Yamak, S., \& Üsdiken, B. (2006). Economic liberalization and the antecedents of top management teams: Evidence from Turkish "big” business. British Journal of Management, 17(3), 177-194.

Yang, M. (2015). Ownership participation of cross-border mergers and acquisitions by emerging market firms. Management Decision, 53(1), 221-246.

Yang, M., \& Deng, P. (2017). Cross-border M\&As by Chinese companies in advanced countries: Antecedents and implications. Thunderbird International Business Review, 59(3), 263-280.

Yaprak, A., Yosun, T., \& Cetindamar, D. (2018). The influence of firm-specific and country-specific advantages in the internationalization of emerging market firms: Evidence from Turkey. International Business Review, 27(1), 198-207.

Yildirim-Öktem, Ö., \& Üsdiken, B. (2010). Contingencies versus external pressure: Professionalization in boards of firms affiliated to family business groups in late-industrializing countries. British Journal of Management, 21(1), 115-130.

Yiu, D. W. (2011). Multinational advantages of Chinese business groups: A theoretical exploration. Management and Organization Review, 7(2), 249-277.

Yurtoglu, B. (2000). Ownership, control and performance of Turkish listed firms. Empirica, 27, 193-222. Retrieved from http://link.springer.com/article/10.1023/A:1026557203261.

Zhang, J., Zhou, C., \& Ebbers, H. (2011). Completion of Chinese overseas acquisitions: Institutional perspectives and evidence. International Business Review, 20(2), 226-238. 